\title{
Aspek Musikologis Gêndér Wayang dalam Karawitan Bali
}

\author{
I Ketut Yasa ${ }^{1}$ \\ Institut Seni Indonesia Surakarta
}

\begin{abstract}
ABSTRAK
Penelitian ini bertujuan untuk mengidentifikasi pola permainan gamelan atau gêndér wayang pada pertunjukan wayang Bali. Gêndér wayang terdiri dari dua pasang instrumen, sepasang gêndér gede dan sepasang gêndér barangan. Kedua pasang gêndér ini menghasilkan pola permainan yang saling mengunci (interlocking figuration) yang sangat khas. Pola permainan ini diberi nama ubitubitan atau cecandetan. Data diperoleh melalui pengamatan terhadap pertunjukan wayang Bali. Berdasarkan penelitian dapat disimpulkan bahwa terdapat 10 ubit-ubitan yaitu nyendhok, bolakbalik nuduk, tulak wali, bolak-balik ngutang, nyalud, uber-uberan, mulek, silih berganti, oles-olesan, dan nguluin. Sedang ritme terdapat 7 jenis, yaitu ngumad, ngambang, ngantung, kesiab, imbuh nada, imbuh gatra, dan salah gatra.
\end{abstract}

Kata kunci: gêndér wayang; karawitan Bali; cecandetan; musik wayang

\begin{abstract}
The Musicological Aspect of Puppet Gêndér on Balinese Gamelan. This study aims to identify patterns of gamelan or puppets play on Balinese puppet performances. The puppet Gêndér consists of two pairs of instruments, a pair of large gêndér gede and a pair of barrels of gêndér. Both pairs of this gender produce a very distinctive interlocking figuration pattern. This play pattern is named ubit-ubitan or cecandetan. The data were obtained through observation of Balinese puppet shows. Based on the research it can be concluded that there are 10 ubitan, namely nyendhok, bolak-balik nuduk, tulak wali, bolak-balik ngutang, nyalud, uber-uberan, mulek, silih berganti, oles-olesan, and nguluin. There are 7 types of rhythms, namely ngumad, ngambang, ngantung, kesiab, imbuh nada, imbuh gatra, and salah gatra.
\end{abstract}

Keywords: gêndér puppet, Balinese karawitan; Cecandetan; wayang music

\section{Pendahuluan}

Dalam klasifikasi gamelan Bali, gêndér wayang digolongkan ke dalam gamelan tua yang diperkirakan ada sebelum abad XIV (Rembang, 1977: 1). Sebuah sumber menyatakan bahwa istilah gêndér wayang semula dikenal dengan istilah salunding wayang. Dalam kakawin Bharatayuda disebut ada istilah salunding wayang seperti yang ditulis oleh Jaap Kunt (1968: 77) berikut.
Tekwan ri Iwah ikang taluktak atarik saksat salunding wayang/pring bungbang muni kanginan manguluwung, yekan tudungnyangiring/gendingstri nya pabandung i prasamanng kungkang karengwing jurang/ cenggerat nya walangkrik atri kamanak tanpantarangangsyani

[Di lembah sungai terdengar derasnya suara tak luk tak bagaikan salunding iringan wayang/sunari (bambu berlubang)

\footnotetext{
Alamat korespondensi: Prodi Seni Karawitan, Fakultas Seni Pertunjukan, Institut Seni Indonesia Surakarta. Jln. Ki Hajar Deantara 19, Kentingan, Surakarta. E-mail: iketutysa53@yahoo.com. HP: 08122599077
} 
berbunyi ketiup angin meraung karena lubang sulingnya miring/seperti lagu reRebongan (lagu iringan wayang putri) yang terjalin ritmis, demikianlah rasanya suara katak-kangkung (enggung) yang terdengar di dalam jurang/memekaknya suara jangkrik ribut ibarat gumanak yang tak henti-hentinya disertai kangsi].

Sesuai dengan namanya yaitu gêndér wayang, maka fungsi utamanya adalah untuk mengiringi pertunjukan wayang. Dengan demikian matihidupnya karawitan gêndér wayang sangat bergantung pada hidupnya pertunjukan wayang. Sampai saat ini pertunjukan wayang dengan iringan karawitan gêndér wayang masih terpelihara dengan baik di Bali, karena pertunjukan wayang sangat diperlukan dalam rangkaian upacara. Selain itu, pertunjukan wayang kulit (parwa) sudah menjadi suatu atraksi yang menarik bagi banyak wisatawan. Hal ini tercermin dari banyaknya pertunjukan wayang yang digelar di hotel-hotel dan di rumahrumah para dalang, termasuk wayang padat berbahasa Inggris (Dibia, 1997: 34).

Seniman-seniman pencipta zaman dulu (seniman tradsi) sangat hebat-hebat, namun mereka tidak ada yang mencantumkan namanya atas karya yang diciptakan. "Dalam masyarakat tradisional pelaku dan pencipta seni tidak diketahui (anonim ...” (Ardipal, 2015: 16). Dengan demikian, maka dalam analisis gending-gending gêndér wayang di bawah ini hanya mencantumkan nama-nama gending tanpa mencantumkan nama penciptanya.

Perangkat gêndér wayang yang terdiri dari dua pasang, selalu ditata secara berpasangan. Dalam arti dapat ditata secara berhadap-hadapan atau berdampingan, bergantung pada ketersediaan tempat dan keperluannya. Penataan tersebut sangat diperlukan untuk memudahkan mengadakan komunikasi, mengingat pola garap gending gêndér wayang banyak yang menggunakan motif jalinan. Ketika memainkan motif jalinan, salah seorang pengrawit menggunakan tabuhan polos yaitu garap gending yang selehnya lebih banyak jatuh pada ketukan matra (on beat), sedangkan pasangannya bermain tabuhan nyangsih yaitu garap gending yang selehnya lebih banyak terjadi pada ketukan di luar matra (off beat). Dari permainan kedua pasangan pengrawit gêndér ini menghasilkan musikalitas dalam bentuk jalinan yang saling mengisi dan mengunci. Untuk lebih jelasnya perhatikan contoh berikut ini.

$\begin{array}{lllllllll}\text { Polos } & : & . & 2 & 3 & . & 3 & 2 & . \\ \text { Sangsih } & : & 5 & 6 & . & 5 & . & 6 & 5\end{array}$.

Banyak seniman karawitan Bali menilai bahwa teknik permainan gêndér wayang sangat sukar. Musik yang dihasilkan menurut Bandem terdapat berbagai jenis ubit-ubitan atau cecandetan (selanjutnya ditulis ubit-ubitan), dan kaya dengan jenis ritme (1983: 18). Berangkat dari penilaian ini, penelitian ini dimaksudkan untuk mengidentifikasi jenis ubit-ubitan dan ritme yang terdapat dalam garap gending-gending gêndér wayang Bali.

\section{Aspek Musikologis Gêndér Wayang}

Aspek musikologis adalah segala aspek yang berhubungan sifat musik-alitas dari suatu perangkat atau ensambel. Adapun yang termasuk dalam aspek musikologis antara lain: ensambel, sistem nada, bentuk lagu, irama, tempo, volume, jalan sajian, dan ritme. Dalam gêndér wayang, aspek musikologis yang dapat dikaji antara lain: ensambel, sistem nada, bentuk gending dan jalan sajian, teknik tabuhan, pola tabuhan, irama, tempo, dan ritme. Namun dalam tulisan ini yang menjadi kajian pokok dalam aspek musikologis adalah ubit-ubitan (bagian dari pola tabuhan dan ritme). Kendati demikian, sebelum sampai pada kajian tersebut, terlebih dahulu dijabarkan sekilas mengenai ensambel, sistem nada, bentuk gending dan jalan sajian, teknik tabuhan, pola tabuhan, irama, tempo, dan volume.

\section{Ensambel}

Ensambel gêndér wayang terdiri dari dua pasang instrumen gêndér, yang sepasang disebut gêndér gede pengumbang dan gêndér gede pengidep); dan yang sepasang lagi berupa gêndér barangan (pengisep dan pengumbang). Instrumen-instrumen ini dalam penyajiannya ditata secara berpasangan satu sama lain. Gêndér gede pengisep berpasangan dengan gêndér gede pengumbang, dan gêndér barangan pengisep berpasangan gêndér barangan pengumbang. Hal ini berkaitan dengan fungsi/ kedudukan gên- 
dér masing-masing, yakni yang satu memainkan pukulan polos, dan pasangannya memainkan pukulan sangsih. Dengan adanya pembagian tugas/ kedudukan gêndér seperti ini, maka para pengrawit memerlukan komunikasi, lebih-lebih ketika menyajikan gending yang memiliki garap jalinan berupa ubit-ubitan (Gambar 1).

\section{Sistem Nada}

Kendatipun dalam gêndér wayang terdapat sepuluh bilah, namun nada-nada yang terkandung di dalamnya terdiri dari lima nada yang masingmasing memiliki simbol dan nama. Di dalam notasi dingdong, nada-nada diberi simbol Sandang Aksara Bali (Penganggen Sastra Bali) yang diberi nama:ulu, tedong, talèng, suku, dan cêcêk. Secara berturutturut dibaca nding,ndong, ndèng, ndung dan ndang. Di dalam notasi Kepatihan, nada diberi simbol angka Arab: 12356 (1991: 74). Untuk memudahkan di dalam penotasian, maka dalam tulisan ini digunakan notasi Kepatihan. Dengan demikian, urutan nada-nada gêndér wayang yang tersusun dari kiri:

ndong, ndeng, ndung, ndang, nding, ndong, ndeng, ndung, ndang, nding ditulis menjadi:

\section{$\begin{array}{llllllllll}2 & 3 & 5 & 6 & 1 & 2 & 3 & 5 & 6 & 1\end{array}$}

Pengambilan wilayah nada-nada antara gêndér gede dengan gêndér barangan terdapat perbedaan.

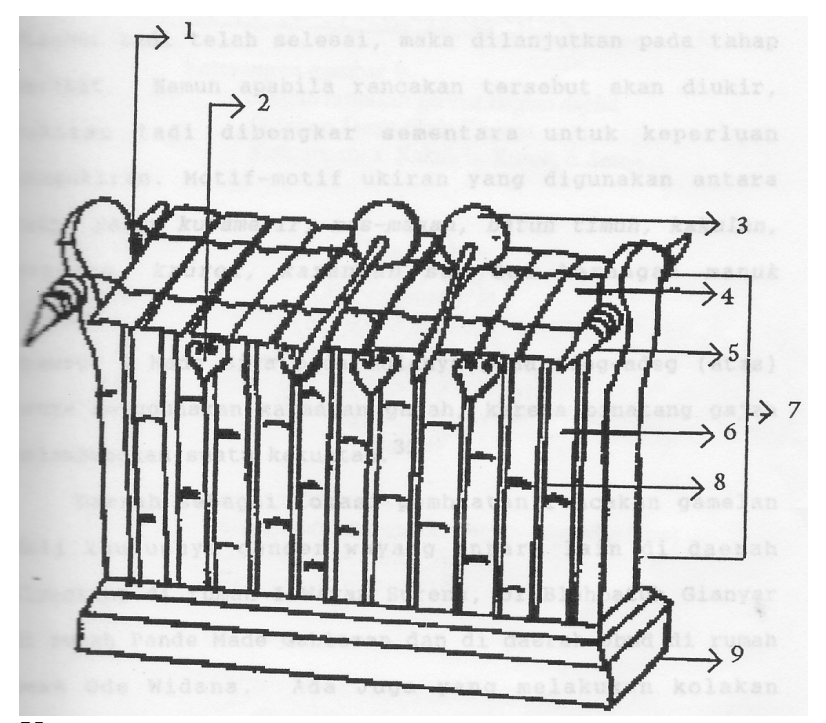

Keterangan:
1. Jangat
4. Bilah
7. Adeg-adeg
2. Cagak
5. Kuping
8. Penyela
3. Panggul
6. Bumbung
9. Duplak

Gambar 1. Gêndér wayang dan bagian-bagiannya
Pengambilan wilayah nada-nada gêndér barangan dimulai dengan gembyang atas dari gêndér gede, sehingga susunannya menjadi seperti berikut.

Gêndér gede: $\begin{array}{lllllllll}2 & 3 & 5 & 6 & 2 & 3 & 5 & 61\end{array}$

Gêndér barangan:

23556123561

Dengan demikian, nada gêndér barangan satu gembyang lebih tinggi dibanding dengan nada gêndér gede. Hal ini menimbulkan kesan tersendiri terhadap tinggi rendah nada dalam gêndér wayang.

\section{Bentuk Gending dan Jalan Sajian}

Bentuk gending dalam karawitan gêndér wayang sedikitnya terdiri dari dua bagian (bentuk) yakni (1) kawitan, dan (2) pengecet/pengadeng. Ada pula yang terdiri dari tiga bagian yaitu (1) pengawak, (2) pengecet dan (3) pengipuk/pekaad.

Jalan sajian gending-gending gêndér wayang pada umumnya dimulai dengan bagian atau bagian pengawak untuk gending yang bagian kawitannya menjadi satu dengan pengawak. Hampir semua gending gêndér wayang, pada bagian pengawak-nya dimainkan secara berulangulang sesuai dengan kebutuhan. Sebagai contoh gending Gending Rebong. Jalan sajiannya dimulai dari bagian pengawak (diulang-ulang), kemudian melalui rambatan atau peralihan menuju ke bagian pengecet. Setelah bagian pengecet dimainkan secara berulang-ulang, dilanjutkan ke bagian pengipuk, yang juga melalui rambatan. Dari bagian pengipuk (yang juga dimainkan berulang-ulang) dengan tempo semakin lambat dan volume semakin lirih, kemudian sajian Gending Rebong berakhir (selesai).

\section{Teknik Tabuhan}

Karawitan gêndér wayang sangat kaya dengan teknik tabuhan, karena dalam permainannya menggunakan berbagai teknik, yaitu dari menabuh hanya satu nada yang disebut dengan Ekacruti, dan menabuh dua buah nada secara bersamaan dengan mengapit satu nada, hingga mengapit delapan nada (perhatikan contoh). Secara keseluruhan, teknik menabuh seperti di atas disebut dengan Kumbangtarung (Bandem, 1986: 69). Berikut ini contoh penerapan dalam wilayah nada gêndér wayang secara berturut-turut dari kecil/tinggi hingga rendah/besar: 


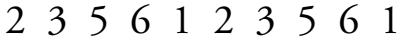

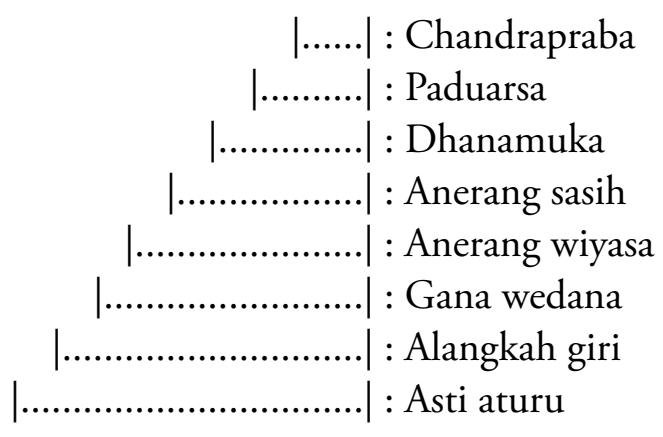

\section{Pola Tabuhan}

Di samping tenik tabuhan, dalam karawitan gêndér wayang juga terdapat berbagai pola tabuhan. Pola tabuhan dalam karawitan gêndér wayang bisa dibagi menjadi dua kelompok besar yakni yang ditabuh oleh tangan kiri dan yang ditabuh oleh tangan kanan. Kelompok yang ditabuh oleh tangan kiri pada umumnya bersifat melodic, sedangkan yang ditabuh oleh tangan kanan pada umumnya bersifat kotekan, yaitu hasil mengkotek atau dalam hal ini menabuh dua buah nada ke arah lebih tinggi (motif ascending), dan menabuh dua buah nada ke arah lebih rendah (motif descending).

Contoh. 56.65 .6 (ascending), dan . 56.5 .65 (descending).

Berikut ini contoh tabuhan tangan kiri (notasi di bawah garis) yang berupa melodi bersama dengan tabuhan tangan kanan (notasi di atas garis) berupa kotekan.

.5 .65 .56 .5 .65 .56 .5 .65 .56 .5 .65 .56

$\ldots \ldots .3 \ldots 1 \ldots 2 \ldots 6 \ldots 6$

Apabila pola kotekan (tabuhan polos), dipadukan dengan pola kotekan (tabuhan penyandet) akan menghasilkan jalinan yang saling mengisi dan mengunci. Perpaduan pola tabuhan inilah yang disebut dengan ubit-ubitan.

Berikut ini sebuah contoh ubit-ubitan.

.5 .65 .56 .5 .65 .56 .5 .65 .56 .5 .65 .56

1.16 .1 .61 .16 .1 .61 .16 .1 .61 .16 .1 .6

\section{Irama}

Dalam karawitan gêndér wayang terdapat bagian-bagian gending yang menggunakan irama bebas dan irama terikat. Bebas bukan berarti sebebas-bebasnya, namun menurut konvensi yang berlaku baik antar pengrawit, maupun antara pengrawit dengan dalang, ketika gending bersangkutan digunakan untuk mengiringi tembang dan ucapan dalang. Sementara irama terikat maksudnya irama yang telah ditentukan oleh matra-matra yang terdapat dalam gending. Sebagai contoh dapat diamati pada awal gending Cecek Megelut sebagai berikut:

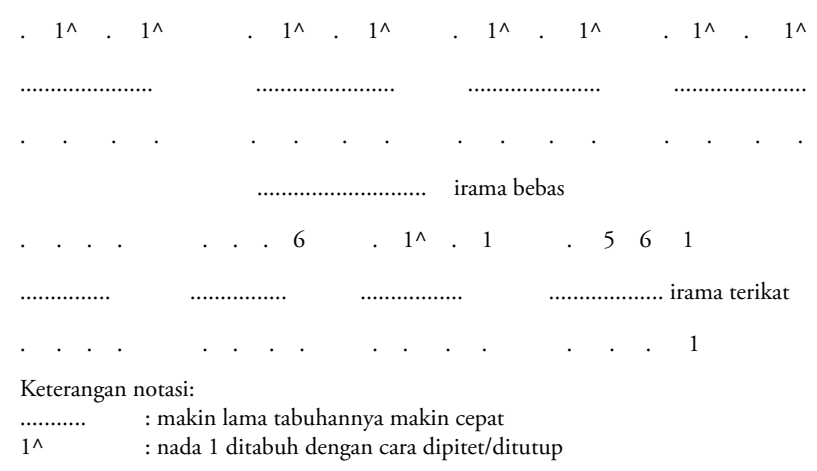

\section{Tempo dan Volume}

Kedua elemen ini dalam garap karawitan Bali khususnya gêndér wayang, seolah-olah tidak dapat dipisahkan satu dengan lainnya, karena dalam karawitan gêndér wayang antara garap tempo dengan garap volume hampir selalu bergandengan. Artinya, jika ada gending yang digarap temponya cepat, volumenya lebih banyak digarap keras, begitu pula sebaliknya.

Dalam karawitan, gêndér wayang mengandung enam jenis garapan tempo yakni: (1) Presto (sangat cepat), terdapat dalam gending-gending batel pesiat dan gending-gending angkat-angkatan; (2) Alegro (cepat) terdapat dalam gending kekayonan; (3) Moderato (sedang), terdapat dalam gending Rebong (bagian Pengawak dan Pengecet), dan gending Pemungkah (bagian Tulang Lindung; (4) Adanta (agak lambat), terdapat dalam gending Gegilak Panyuwud; (5) Linto (lambat), terdapat dalam gending kelompok Petangkilan (bagian Alas Arum, Pengalang Ratu); dan (6) Largo (sangat lambat), terdapat dalam kelompok gending Tetangisan seperti Mesem dan Bendu Semara.

Adapun mengenai volume, dalam karawitan gêndér wayang meng-andung dua pengertian yakni: (1) volume yang dihasilkan oleh perangkat itu sendiri (gêndér wayang), dan (2) volume yang digunakan oleh gending ber- sangkutan. Pengertian 
yang pertama, bila dibandingkan dengan volume yang dihasilkan oleh perangkat gamelan Bali lainnya seperti Gong Kebyar ataupun Gong Gede, maka volume yang dihasilkan oleh perangkat gêndér wayang sudah tentu lebih lirih. Namun demikian, karawitan gêndér wayang sudah dipandang mampu dan atau memadai untuk mengiringi pertunjukan wayang kulit Parwa. Pengertian yang kedua, volumenya hampir selalu bergandengan dengan elemen tempo dalam satu gending. Sebagai contoh gending yang temponya sangat cepat dan atau cepat, volumenya akan lebih banyak keras. Sebagai contoh Gending Batel Pesaiat. Sebaliknya gending yang temponya sangat lambat lebih banyak menggunakan volume sangat lirih. Sebagai contoh adalah gending kelompok Tetangisan.

\section{Jenis Ubit-Ubitan}

Ubit-ubitan merupakan perpaduan dari dua pola tabuhan kotekan yang menghasilkan jalinan yang saling mengisi dan mengunci. Dalam gendinggending gêndér wayang terdapat beberapa jenis ubit-ubitan, yaitu: nyendok, tulak wali, bolak-balik nuduk, bolak-balik ngutang, nyalud, uber-uberan, mulek, oles-olesan dan silih berganti. Ubit-ubitan tadi tersebar dalam beberapa gending seperti kelompok Petegak: Atma Prsangka, Merak Ngelo, Sekar Gendot, Sekar Taman; Pemungkah: bagian ke tiga, ke empat, ke enam, dan bagian ke delapan; Pangkat: Bimaniyu, Bima Kroda, Pangkat Cenik Pngesah; Pepeson: Bapang Delem dan Sangut, Arasarasan: Rebong, dan kelompok Panyuwud: Gegilak.

\section{Nyendok}

Jenis ubit-ubitan "nyendok" terdapat dalam gending Pamungkah bagian ke empat (pada peralihan) menuju ke gending Pamungkah bagian ke lima. Gending ini bisanya disajikan ketika adegan wayang sedang megunem (Jawa: Jejer), selama satu rambahan dengan tempo relatif cepat, dan volume relatif keras, teknik tabuhan anerang sasih, dan guna widana dengan irama terikat.

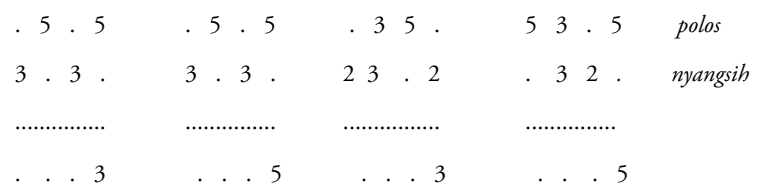

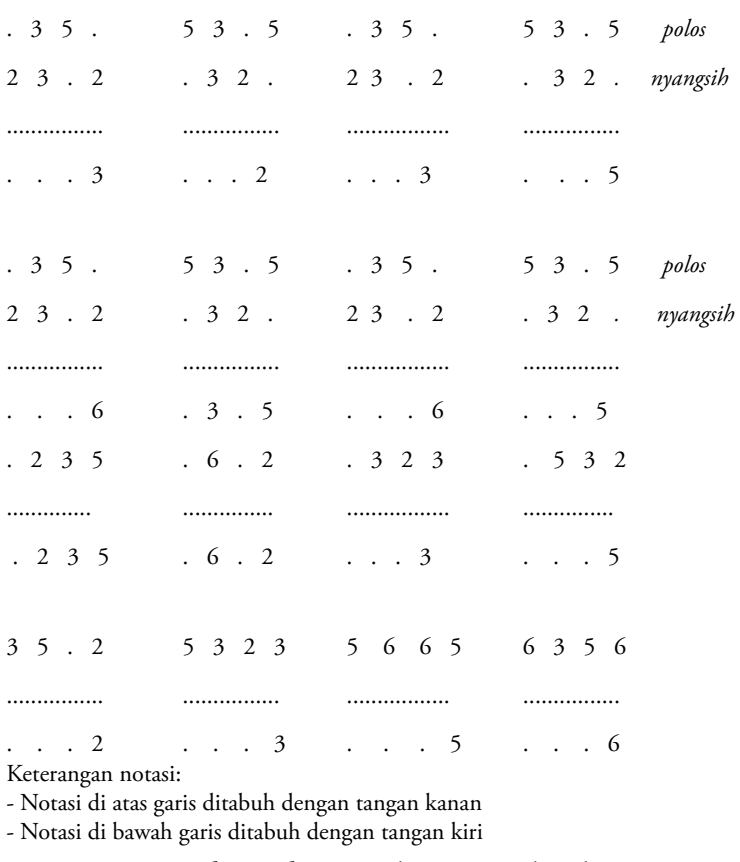

Jenis ubit-ubitan di atas disebut nyendok, karena ubit-ubitan di atas sejenis dengan ubit-ubitan gending Gegaboran dalam gamelan Palegongan yang oleh I Made Bandem disebut dengan Nyendok. Adapun ubit-ubitan yang dimaksud adalah seperti berikut:

Balungan :

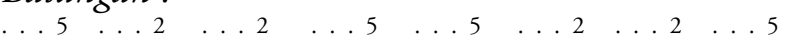

Polos:

35.53 .5
.35 .53 .5 .35 .53 .5 .35 .53 .5

Sangsih :

23.2.32. 23.2 .32 .23 .2 .32 .23 .2 .32$.

Dikaji dari istilahnya, kata "Nyendok" berarti mengambil sesuatu dengan sendok. Kata ini memiliki konotasi menyentuh sesuatu nada secara berturut-turut dua kali seperti nampak dalam tabuhan . 35.53 .5 dan seterusnya. Dilihat dari bentuknya, ubit-ubitan ini sangat sederhana yaitu memiliki satu motif seperti . 35.53 . 5, namun pola ini diulangulamg sesuai dengan kebutuhan. Dalam Bapang Gegaboran seperti gending di atas, motif ini diulang sampai empat kali untuk memenuhi balungan. Demikian pula halnya dengan cuplikan Gending Pamungkah di atas, bahwa untuk memenuhi balungannya, pola tersebut harus diulang hingga enam kali (kalimat gending I, gatra ke tiga, hingga kalimat gending ke III, gatra ke empat).

\section{Tulak Wali}

Ubit-ubitan ini terdapat dalam gending kelompok Pepeson yang bernama Bapang Delem. 
Gending ini digunakan untuk mengiringi tampilnya punakawan Delem dan Sangut dalam pertunjukan wayang kulit. Gending ini disajikan secara berulang-ulang dengan tempo pelan dan volume sedang serta teknik tabuhan Ekacruti, berirama terikat. Adapun notasinya sebagai berikut: Polos

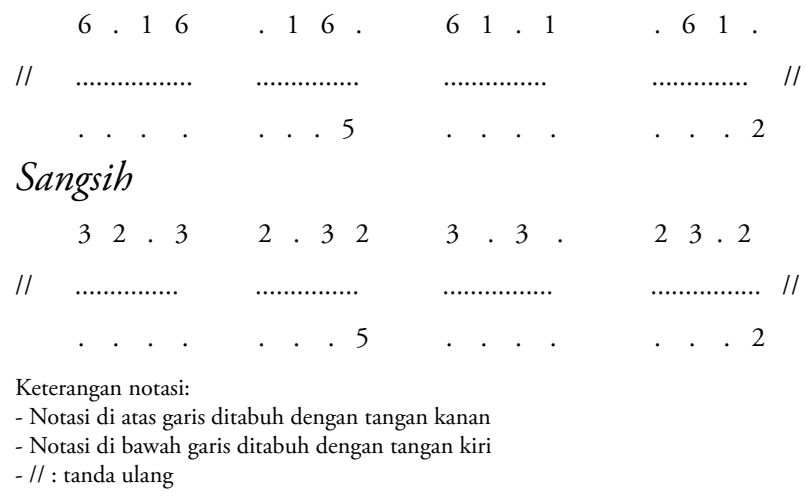

Dinamakan jenis Tulak Wali, karena ubitubitan di atas sejenis dengan ubit-ubitan yang terdapat pada Gending Gegaboran dalam gamelan Palegongan, yang oleh I Made Bandem disebut dengan Tulak Wali. Ubit-ubitan yang dimaksud adalah seperti di bawah ini.

Balungan: . . 2 ..6 . . 6 .. 2 Polos: 16.153 .5 .35 .53 .5 Sangsib:. 32.32 .3 .23 .23 .2

Disebut jenis ubit-ubitan Tulak Wali didasarkan atas pengertian bahwa Tulak Wali adalah sistem polos sangsih bolak-balik. Dalam kebanyakan sistem ubit-ubitan yang lain, tabuhan polos jatuh pada ketukan matra (on beat), dan tabuhan sangsih jatuh pada ketukan di luar matra (off beat). Namun yang terjadi dalam ubit-ubitan jenis Tulak Wali adalah hal yang sebaliknya.

Bagian lainnya yang menarik dari ubit-ubitan ini adalah bahwa Tulak Wali terdiri dari dua motif yaitu A: 16 . dan B: . $6 \begin{array}{llllll}6 & 1 & & 6 & 1 & \text {..Untuk }\end{array}$ membalikkan unit $\mathrm{A}$ menjadi unit $\mathrm{B}$ atau dari motif descending (turun) menjadi motif ascending (naik), maka diselipkan sebuah transisi (sisipan) $\begin{array}{llll}1 & 6 & 1\end{array}$. Dengan demikian, pengertian bolakbalik yang terdapat dalam ubit-ubitan Tulak Wali terjadi prinsip sistem (polos-sangsih) dan pada prinsip motif. Sementara, ubit-ubitan dalam Gending Bang Delem juga terjadi hal yang sama, baik prinsip sistem maupun pada prinsip motif , sehingga penulis beri nama ubit-ubitan Tulak Wali.

\section{Bolak-Balik Nuduk}

Jenis ubit-ubitan ini terdapat pada bagian akhir (pekaad) dari Gending Rebong. Gending ini biasanya digunakan untuk mengiringi adegan romantis. Tempo yang digunakan relatif cepat dengan volume keras, lebih-lebih menjelang angsel. Gending ini disajikan secara berulang-ulang sesuai degan kebutuhan dengan teknik tabuhan Ekacruti, dan berirama terikat.

Polos

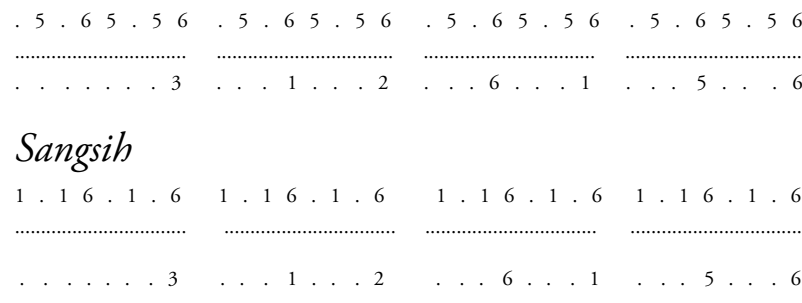

Jenis ubit-ubitan di atas disebut jenis bolak-balik nuduk, didasarkan atas pola kotekan (perhatikan tabuhan polos) yang bersifat bolakbalik. Sementara kata nuduk yang artinya memunggut, merupakan istilah yang dipinjam dari nama tabuhan gêndér rambat yang motifnya mengarah ke nada yang lebih tinggi (naik). Sebagai contoh 35 6, 56 1. Demikian pula jenis ubit-ubitan bolak-balik nuduk ini, selain bersifat bolak-balik, juga berakhir dengan arah nada yang lebih tinggi.

Kata $n u d u k$ yang mengikuti kata bolak-balik, diartikan dengan me-munggut, bisa juga diartikan dengan mengambil atau menerima. Kemudian ubit-ubitan berikut ini, ada kata ngutang yang berarti membuang/meninggalkan, bisa juga bararti memberikan. Kedua pengertian ini (nuduk dan ngutang) mengandung maksud, bahwa di dalam hidup bermasyarakat harus siap menerima sesuatu, juga harus siap memberi sesuatu kepada orang lain.

\section{Bolak-Balik Ngutang}

Jenis ubit-ubitan ini, terdapat pada Gending Atma Prasangka, yang merupakan Gending Petegak. Gending ini disajikan ketika dalang sedang mempersiapkan segala sesuatu yang berkaitan dengan pertunjukannya, disajikan secara berulangulang sesuai dengan kebutuhan, dalam tempo dan volume relatif sedang, dengan teknik Ekacruti berirama terikat. 


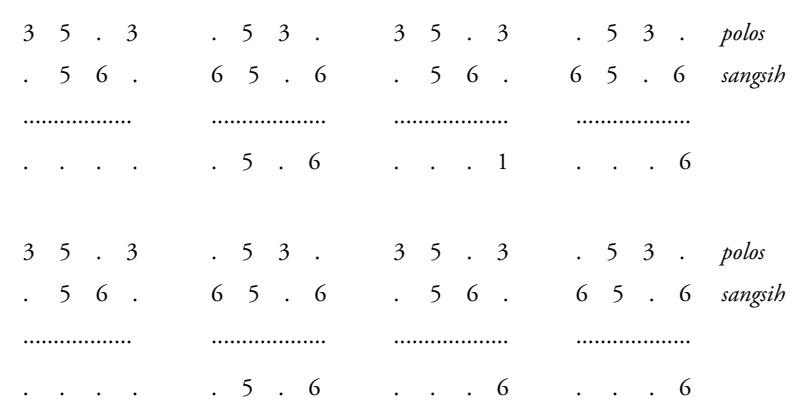

Jenis ubit-ubitan bolak-bolik ngutang merupakan kebalikkan dari jenis ubit-ubitan bolakbolak nuduk, karena arah nadanya berakhir ke arah yang lebih rendah (perhatikan pola tabuhan tangan kanan bagian tabuhan polos). Istilah "ngutang" yang artinya membuang/meninggalkan, juga dipinjam dari nama salah satu pola tabuhan gêndér rambat, yang bentuknya antara lain: 653 , dan atau 53 2, dan seterusnya.

\section{Nyalud}

Jenis Ubit-ubitan ini terdapat dalam gending Gegilak Penyuwud. Gending ini biasanya digunakan sebagai penutup dari pertunjukan atau bagian akhir dari rangkaian sajian. Disajikan secara berulangulang sesuai dengan kebutuhan, dalam tempo agak lambat dan volume agak lirih; dengan teknik tabuhan Ekacruti, dan berirama terikat. Contohnya sebagai berikut:

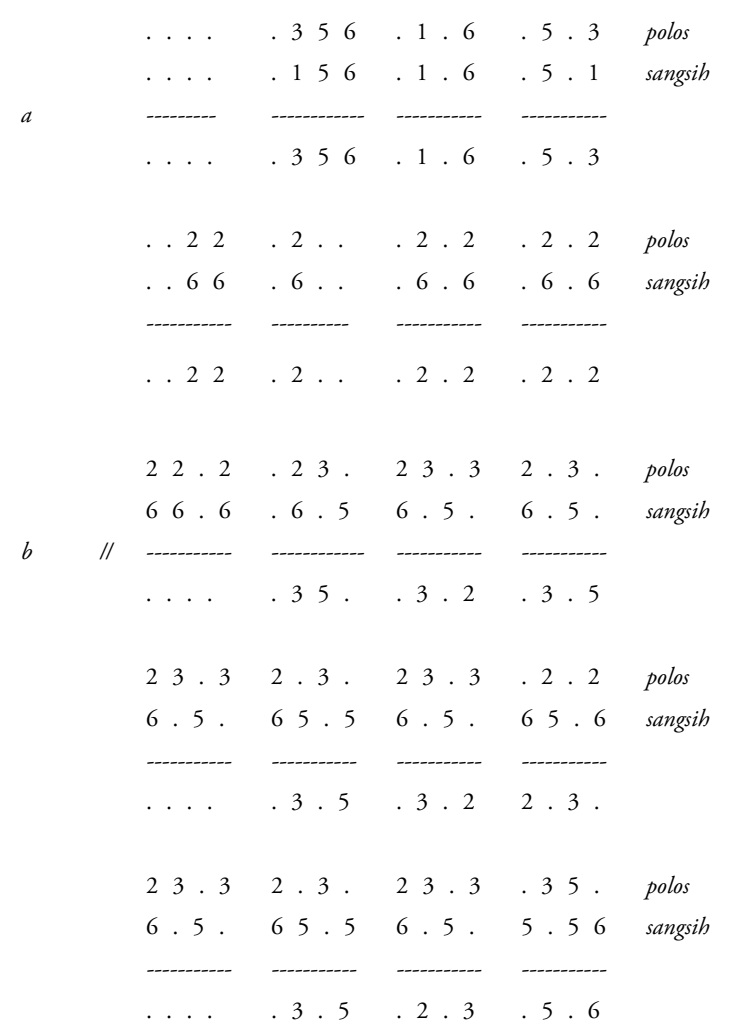

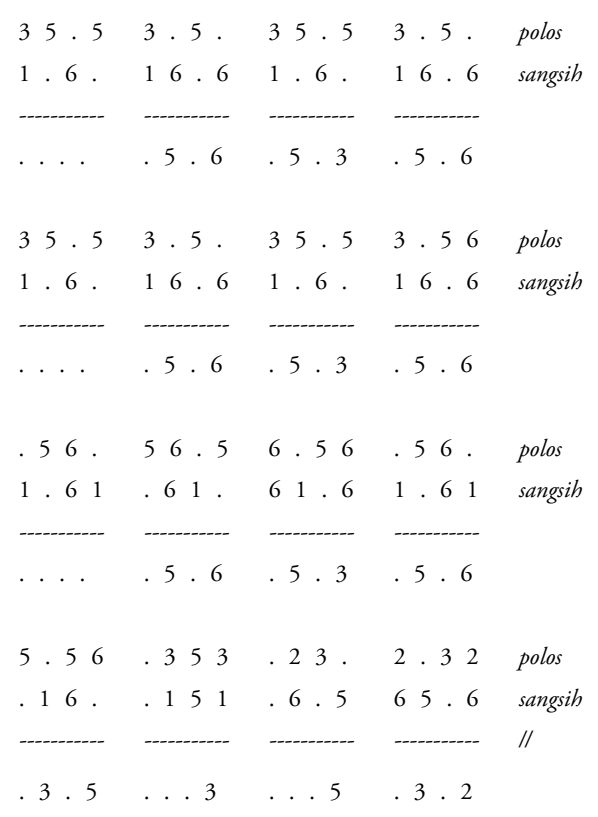

Jika diperhatikan, pukulan tangan kanan bagian polos notasi pada kalimat gending II dan III, tertulis $2 \quad 3.3 \quad 2.3$. yang diulang-ulang. Demikian pula pada kalimat gending IV dan V, tertulis $35.5 \quad 3.5$. yang diulang-ulang.

Kata "nyalud," bagi masyarakat Bali dipahami sebagai mengambil air dengan timba dari bawah permukaan air. Ubit-ubitan nyalud memiliki pula konotasi mengambil (menabuh nada) melalui nada di bawahnya. Misalnya kalimat gending yang berseleh nada 5 akan diambil melalui nada 2 3.32 .3 ., dan kalimat gending yang berseleh 6 akan diambil melalui 35.53 .5 . begitu pula seterusnya.

Pengertian nyalud mirip dengan pengertian nyendok yaitu sama-sama mengambil sesuatu. Hanya saja dalam pengertian nyalud ada kalimat yang mengatakan mengambil dari bawah. Kalimat mengambil dari bawah ini, jika dicermati akan ditemukan maksud, bahwa setiap memulai sesuatu harus mulai dari bawah atau dari awal.

\section{Uber-uberan}

Jenis ubit-ubitan ini juga terdapat pada Gending Panyuwud yang bernama Gegilak. Bila diperhatikan kalimat gending VI di atas, tertulis 56 . yang diulang-ulang. Kata "uber-uberan" merupakan sinonim dari kata kejar-kejaran. Dalam konteks ubit-ubitan di atas, nada 5 dan 6 juga berkesan seperti saling kejar karena disajikan secara berulang-ulang. Kata uber-uberan di atas diberi arti 
dengan saling kejar. Pengertian ini bermakna bahwa dalam kehidupan ini penuh dengan persaingan/ kempetisi, yang lengah, lemah dan atau lamban, akan ketinggalan oleh yang penuh konsentrasi, kuat dan cepat.

\section{Mulek}

Jenis ubit-ubitan ini juga terdapat dalam Gending Gegilak di atas. Jika diperhatikan kalimat lagu VII (terakhir), terdapat tiga motif kotekan yaitu (a) 5.65 (b). 353 dan (c). 23.2 . 3 2. Ketika tiga motif ini disatukan dalam satu kalimat gending, terbentuklah jenis ubit-ubitan Mulek. Disebut Mulek karena dari motif a hingga motif c terjadi arah yang dapat dikata kan balikbolak-balik. Disebut Mulek karena terjadinya arah balik-bolak-balik.

\section{Oles-olesan}

Jenis ubit-ubitan ini, terdapat pada Gending Pamungkah bagian ke empat. Gending Pamungkah digunakan ketika dalang membuka gedog kotak wayang hingga "ngesah kayonan". Gending ini disajikan selama satu rambahan dalam tempo dan volume relatif sedang, dengan teknik tabuhan Anerang sasih dan Asti aturu, serta berirama terikat.

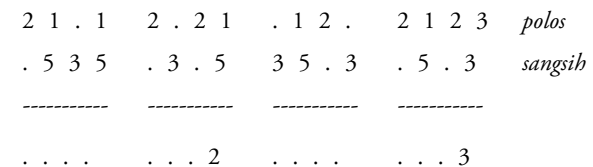

Disebut oles-olesan, karena ubit-ubitan ini sejenis dengan ubit-ubitan yang terdapat pada gending Gegaboran dalam Gamelan Palegongan yang menurut I Made Bandem disebut oles-olesan. Gending yang dimaksud adalah seperti berikut.

Balungan :

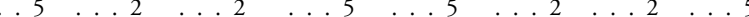

Polos:

32.23 .3
3223.323 .32 .23 .32 .23 .323 Sangsih:

.5 .656 .5 .656 .56 .5 .656 .5 .656 .56 .5

Secara harfiah kata "oles-olesan" berarti poles atau gosok. Dalam konteks ubit-ubitan oles-olesan dimaksudkan sebagai teknik permainan yang di dalam musik Barat disebut sliding. Sistem sliding dalam jenis ubit-ubitan ini tertera pada tabuhan nada-nada .32.23.32.23. dan teknik ini dimainkan dengan cara menabuh tanpa bertekanan keras.
Berbeda dengan teknik-teknik lain yang dalam setiap tabuhan nada ditandai dengan ritme stacato terputus-putus dengan tekanan berat. Jenis ubitubitan seperti ini juga terdapat dalam gending gêndér wayang yang bernama Sekar Setaman.

\section{Silih Berganti}

Jenis ini terdapat dalam Gending Pamungkah bagian kedelapan. Gending ini disajikan secara berulang-ulang dalam tempo dan volume relatif sedang, teknik tabuhan Chandrapraba, Paduarsa, dan Dhanamuka, dan berirama terikat.

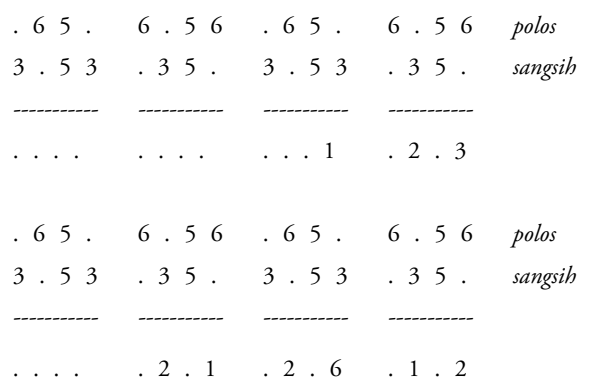

Secara harfiah, kata silih berganti berarti gantian atau secara bergantian. Hal ini nampak pada teknik permainan dengan menabuh nadanada antara 5 dan 6 secara bergantian, seperti yang tertera dengan pola 6 5.6 . 5 6. Oleh karena itu, jenis ubit-ubitan di atas penulis beri nama silih berganti. Jenis ubitubitan silih berganti ini juga terdapat pada Gending Pemungkah bagian kedua.

\section{Jenis Ritme}

Sebelumnya telah disinggung bahwa ritme diandaikan sebagai elemen waktu dalam musik yang dihasilkan oleh dua faktor yaitu: aksen dan panjang-pendek nada atau durasi. Aksen adalah tekanan atas sebuah nada untuk membuatnya berbunyi lebih keras. Aksen dapat muncul pada nada mana saja dalam suatu rangkain ketukanketukan yang berulang secara teratur. Aksen yang demikian itu akan menghasilkan ritme. Ritme juga dapat dihasilkan dari kombinasi nada-nada dari durasi yang berbeda yakni: dua nada pendek dan sebuah nada panjang, atau sebuah nada panjang dengan beberapa nada pendek. Oleh karena salah satu aksen atau durasi dapat menghasilkan ritme, maka dengan sendirinya kedua elemen tersebut dapat digabungkan untuk menghasilkan ritme. 
Berangkat dari pengertian ritme di atas, dalam gending-gending gêndér wayang ditemukan beberapa jenis ritme, yakni: nguluin, ngumad, ngambang, kesiab, imbuh nada, imbuh gatra, salah gatra, dan ngantung. Berbagai jenis ritme tadi tersebar pada gending-gending gêndér wayang antara lain : kelompok Petegak: Sekar Sungsang, Sekar Gendot, Sekar Taman, Cangak Merengang, Gineman Cecek Magelut, Katak Ngongkek, Dalang Ngidih Nasi, Gelagah Puwun, Merak Ngelo. Kemudian pada gending-gending gêndér wayang kelompok Pamungkah: ke tiga, ke empat, ke enam. Selanjutnya gending-gending gêndér wayang kelompok Petangkilan: Penyacah Parwa; kelompok Pangkat: Bimaniyu, Bima Kroda, Burisrawa, Kajojor, Krepetan, Pangkat cenik. Terakhir kelompok Pepeson: Bapang Delem dan Sangut.

\section{Nguluin}

Jenis ini terdapat dalam gending Sekar Gendot gaya I Wayan Konolan (Sukerna, 1989: 89) dan (Sueca, 1985: Vol. 1. -643). Gending ini merupakan kelompok petegak (instrumentalia), untuk mengantar atau sebagai pemberitahuan kepada penonton bahwa pertunjukan segera dimulai. Gending ini disajikan ketika dalang sedang mempersiapkan segala sesuatunya yang berkaitan dengan pertunjukan.

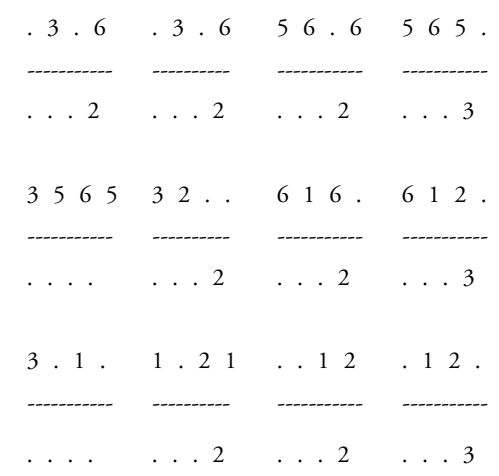

Jika diperhatikan tabuhan tangan kanan pada kalimat gending bagian ke II, gatra ke kedua (3 2 . . ) yang dicetak tebal di atas, tekanan/aksen yang agak kuat justru terjadi pada ketukan ke dua (nada 2). Ritme yang sama juga terdapat pada gending yang sama dari sekaa gêndér wayang desa Tunjuk, Tabanan, dan pada gending Sekar Gendot gaya sekaa Gêndér Wayang Banjar Babakan, Sukawati, Gianyar.
Padahal tekanan seperti itu seharusnya terjadi pada ketukan ke empat (tempat seleh). Dengan demikian kasus ini dapat dikatakan bahwa seleh gending mendahului tempat seleh. Garap seperti ini juga sering dilakukan pada garap trompong dalam gending-gending gong gede. Garap trompong seperti ini diberi nama "nguluin" yang berasal dari kata "ngehuluin", yang artinya ke hulu atau mendahului. Oleh karena itu, jenis ritme dalam garap cuplikan gending di atas diberi nama ritme nguluin. Pengertian nguluin di atas ditekankan bahwa sesuatu dilakukan secara mendahului, sedangkan pengertian ngumad dalam ritme di bawah ini ditekakankan pada sesuatu yang dilakukan secara terlambat.

\section{Ngumad}

Jenis ritme ini juga terdapat dalam gending Sekar Gendot. Jika dicermati tabuhan tangan kanan pada kalimat gending bagian ke II, gatra ke empat (6 12.) yang dicetak tebal di atas, tekanan/ aksen yang sangat kuat justru terjadi pada kalimat gending ke III, gatra ke satu, nada pertama ( 3 ). Ritme yang sama juga terdapat pada gending yang sama dari sekaa gêndér wayang desa Tunjuk, Tabanan, pada gending Merak Ngelo dari sekaa Br. Taman, Krobokan, Kuta, Badung.

Padahal nada-nada yang terletak pada ketukan ganjil, pada umumnya memiliki seleh yang tidak sekuat dengan nada-nada yang terletak pada ketukan genap. Ini terjadi karena nada 2 pada gatra ke empat dari kalimat gending ke II, berdurasi panjang. Akibatnya, akhir kalimat gending yang seharusnya memiliki seleh kuat, kedengarannya tidak ada seleh, karena selehnya (nada 3) ditunda (diulurulur), sehingga terletak pada kalimat berikutnya.

Dengan terjadinya kasus di atas, maka ritme seperti itu disebut dengan " $n g u m a d$ ", istilah yang juga digunakan dalam tabuhan trompong. Istilah ini bagi masyarakat (seni) Bali dipahami sebagai kata yang berarti mengulur-ulur waktu. Dalam konteks jenis ritme ngumad, kesan mengulur waktu juga nampak dari seleh yang berkesan terlambat. Namun sesungguhnya hal itu memang di sengaja dibuat seperti itu. Ritme jenis (ngumad) ini juga terdapat dalam gending-gending: Cangak Mrengang, Kajojor, Dalang Ngidih Nasi, dan Gelagah Puwun. 
Secara keseluruhan, gending ini menggunakan volume sedang dan lirih. Artinya pada kalimat gending-gending tertentu menggunakan volume sedang, sedangkan pada kalimat gending lainnya menggunakan volume lirih. Seperti cuplikan gending di atas, volume sedang terjadi pada kalimat gending ke II hingga ke III, sedangkan volume lirih terjadi pada kalimat gending ke I.

Adapun tempo yang digunakan dalam Gending Sekar Gendot adalah tempo yang relatif sedang dan agak lambat. Sementara cuplikan gending di atas menggunakan tempo relatif sedang; disajikan secara berulang-ulang sesuai kebutuhan, dengan teknik tabuhan Ekacruti; pola tabuhan bersifat melodic, dan berirama terikat.

\section{Ngambang}

Jenis ini terdapat pada gending kelompok pepeson yang bernama gending iringan Delem dan Sangut. Gending ini disajikan dengan gending Bapang Delem. Gending ini khusus digunakan untuk mengiringi keluarnya punakawan Delem bersama punakawan Sangut. Gending ini disajikan menggunakan tempo relatif pelan dan volume relatif sedang secara berulang-ulang sesuai kebutuhan, dengan pola tabuhan kotekan tangan kanan dan melodi tangan kiri, teknik tabuhan Ekacruti, dan berirama terikat.

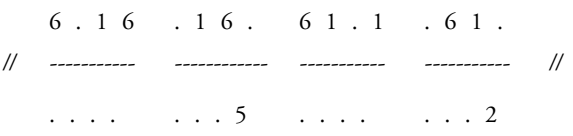

Jika diperhatikan, tabuhan tangan kanan bagian gatra pertama gending di atas, tekanan yang sangat kuat justru terjadi pada nada pertama. Ini terjadi karena nada 6 tersebut berdurasi panjang. Akibatnya, akhir kalimat gending yang seharusnya memiliki seleh kuat (nada 2) hampir tidak terdengar karena ditarik secara terburuburu dengan membalikkan seleh 2 ke seleh 5 (lihat tabuhan tangan kiri). Oleh karena nyaris tidak terdengarnya seleh yang seharusnya kuat ini, maka penulis menawarkan jenis ritme ini bernama ngambang.

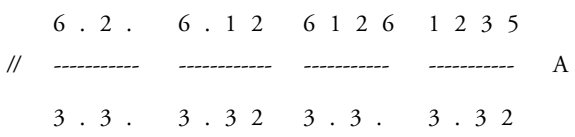

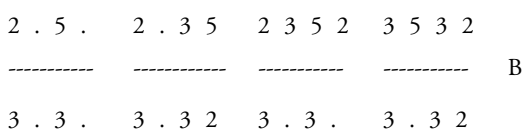

Jenis ritme ngambang juga terdapat pada bagian gending Pangkat atau angkat-angkatan. Gending ini biasanya digunakan untuk mengiringi tokoh wayang berangkat ke medan perang. Gending disajikan secara berulang-ulang sesuai dengan kebutuhan, tempo relatif cepat dan volume relatif keras, teknik tabuhan Gana Wedana, pola tabuhan melodis, dan berirama terikat.

Bila disimak gending di atas, ditemukan dua unsur pembentuk ritme yakni aksen/tekanan dan durasi waktu. Kedua unsur tersebut terdapat pada gending A maupun gending B gatra pertama dan kedua. Gending A gatra ke empat, yang semestinya mendapat aksen kuat karena merupakan akhir kalimat gending atau seleh gending, akan tetapi malah berkesan ngambang, karena seleh 5 pada gatra ke empat gending tersebut ditarik oleh nada 2 ke gatra pertama gending B. Akibatnya seleh yang kuat justru terjadi pada gatra pertama gending B. Kasus yang sama terjadi pula dari seleh akhir gending B ke gatra pertama gending A. Di samping itu, nada 6 pada gatra kedua gending A, dan nada 2 pada gatra kedua gending B, yang terletak pada ketukan ganjil, yang pada umumnya beraksen lemah, namun pada gending di atas justru berkesan nada seleh yang kuat. Kasus ini tiada lain disebabkan oleh durasi panjang yang dimiliki oleh kedua nada tersebut.

\section{Ngantung}

Jenis ini terdapat dalam gending Penyacah Parwa. Gending ini tergolong kelompok gending petangkilan, untuk mengiringi ketika dalang mengucapkan deskripsi suatu adegan. Gending ini disajikan secara berulang-ulang sesuai dengan kebutuhan, tempo dan volume relatif sedang, teknik tabuhan Ekacruti, pola tabuhan melodis, dan irama terikat.

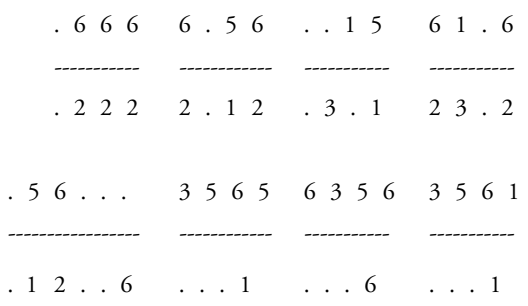


Jika dicermati pola tabuhan tangan kiri maupun pola tabuhan tangan kanan dari cuplikan gending di atas, pada kalimat gending I gatra ketiga bagian nada 3 (tabuhan tangan kiri) dengan bagian nada 1 (tabuhan tangan kanan), nampak terjadi seleh menggantung. Hal ini disebabkan oleh kedua nada tersebut didahului oleh satu atau lebih titik. Demikian pula yang terjadi pada kalimat gending II, gatra pertama bagian nada 6 (tabuhan tangan kiri) yang bergandengan dengan gatra kedua pada bagian nada 3 (tabuhan tangan kanan). Oleh sebab itu ritme tersebut diberi nama jenis ngantung.

\section{Kesiab}

Jenis ini terdapat dalam gending Sekar Gendot. Kesiab disajikan secara berulang-ulang sesuai dengan kebutuhan, dalam tempo relatif cepat dan volume relatif keras dengan teknik tabuhan Ekacruti dan Anerang sasih, pola tabuhan bersifat melodis, dan irama terikat.

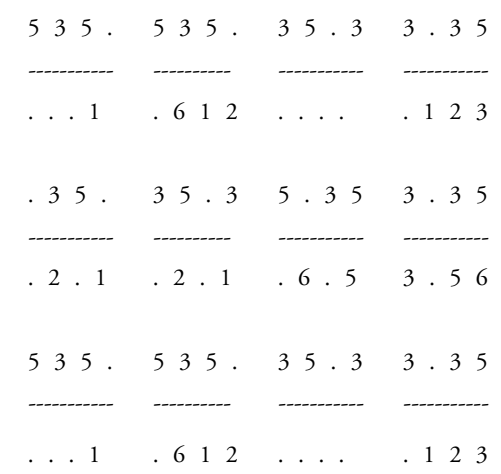

Kesiab berarti kaget atau terkejut. Kata kesiab dalam ritme di atas diartikan sebagai suatu yang dapat membuat orang terkejut atau mengejutkan. Ubit-ubitan jenis ini menimbulkan para pendengar bisa kaget atau terkejut. Hal ini disebabkan oleh beberapa faktor antara lain: pertama, dikagetkan oleh tabuhan yang diawali maupun diakhiri berupa pola kotekan seperti $5 \quad 3 \quad 5.5 \quad 3 \quad 5.3$ 5 . 35 ., kemudian mendadak menjadi tabuhan yang bersifat melodis seperti $3 \quad 5 \quad 3.5 \quad 6$; kedua, ketika diselingi dengan tabuhan yang bersifat melodic dilakukan secara digembyang (kalimat gending II gatra paruh ke tiga dan gatra ke empat); ketiga, dalam tabuhan yang bukan kotekan terdapat nada 3 yang berdurasi panjang: 353.56 .

\section{Imbuh Nada}

Jenis ini terdapat dalam Gending Gineman Cecek Megelut. Gending ini merupakan tabuh petegak (instrumentalia), digunakan untuk memberitahukan para penonton, bahwa pertunjukan segera dimulai. Imbuh nada disajikan secara berulang-ulang ketika dalang sedang mempersiapkan segala sesuatunya yang berhubungan dengan pertunjukan. Gending ini disajikan menggunakan teknik tabuhan Paduarsa dan Anerangsasih, irama terikat, dan tempo maupun volume relatif sedang.

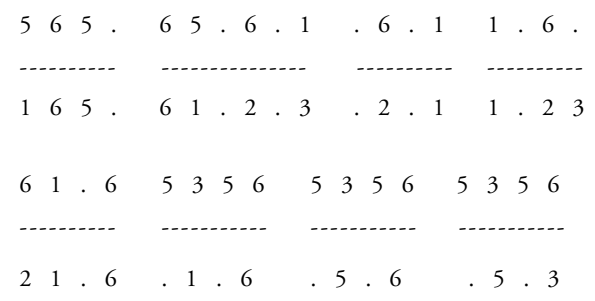

Disebut dengan jenis imbuh nada karena dalam gending tersebut ada imbuhan atau tambahan nada 1 seperti . 6 . 11 (kalimat gending I gatra ke tiga dan paruh gatra ke empat), sehingga selehnya terletak pada nada pertama gatra ke empat. Dalam gending tersebut sebetulnya bisa saja tanpa tambahan nada seperti yang terjadi pada paruh gatra ke empat kalimat gending I dengan paruh gatra pertama kalimat gending II: 6 . 6 1 , sehingga seleh-nya terletak pada tempat yang lebih kuat. Namun barangkali sang komponis memang menghendaki demikian dengan maksud menambah hiasan ritme.

\section{Imbuh Gatra}

Jenis ini terdapat dalam gending kelompok pemungkah bagian kedua. Gending ini disajikan sebagai rambatan menuju pada iringan kayonan. Gending ini disajikan selama satu rambahan dalam tempo dari pelan semakin cepat dan volume dari lirih menjadi keras, teknik tabuhan Paduarsa dan Anerang sasih, pola tabuhan bersifat melodic, dan irama terikat.

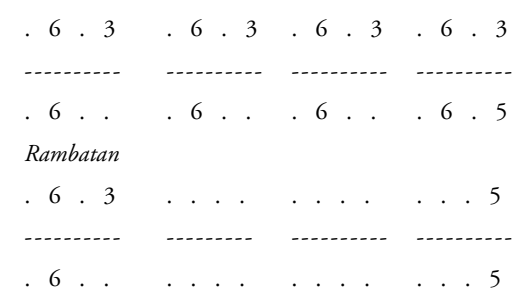




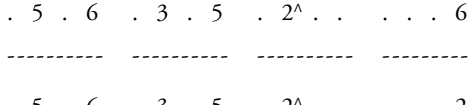

Disebut dengan jenis imbuh gatra, karena gending rambatan ini seolah-olah ada tambahan gatra. Dikatakan seolah-olah, karena tanpa ada tambahan gatra tersebut seleh gendingnya menjadi tidak enak, apalagi temponya digarap dengan dari pelan makin cepat. Jika digunakan berjalan teratur dalam keadaan pelan, maka sekalipun tanpa tambahan gatra, bisa saja terasa seleh pada akhir kalimat gending ( . 2 . .). Sudah barang tentu dengan memindahkan seleh nada 6 dari gatra tambahan (gatra ke lima) ke gatra ke empat, sehingga menjadi . 2 . 6.

\section{Salah Gatra}

Jenis ini terdapat dalam Gending Merak Ngelo. Gending ini merupakan kelompok petegak sebagai pengentar atau memberitahu kepada para penonton bahwa pertunjukan segera dimulai. Gending ini disajikan ketika dalang mempersiapkan segala sesuatunya yang berhubungan dengan pertunjukan wayang. Sajian gending ini menggunakan teknik tabuhan Ekacruti dan Anerang sasih, pola tabuhan bersifat melodis, irama terikat, dan tempo maupun volume relatif sedang.

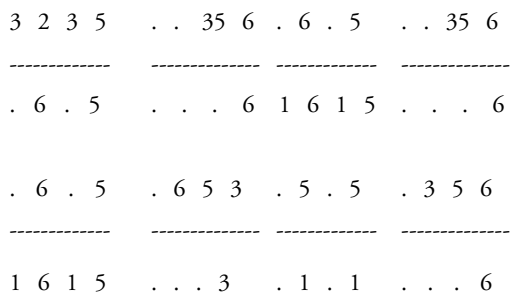

Disebut jenis salah gatra, karena gending ini seleh kuatnya terjadi pada gatra pertama dan ketiga pada kalimat gending I, dan gatra pertama pada kalimat gending II. Padahal, seleh yang kuat pada umumnya terjadi pada akhir gatra II dan akhir gatra IV (pada gatra bilangan genap). Namun pada gending di atas seleh yang kuat justru terjadi pada bilangan ganjil. Hal ini disebabkan oleh nada akhir dari gatra pertama maupun nada akhir dari gatra ketiga di atas, diikuti oleh titik sebagai isyarat ada perpanjangan nada. Oleh karena itu, gatra-gatra tersebut memiliki seleh yang cukup kuat, yang sebetulnya pada gatra yang salah.
Jika diperhatikan dengan seksama namanama atau istilah di atas, maka dapat dijumpai bahwa sebagian besar nama-nama tersebut, selain disesuaikan dengan karakter dari Ubit-ubitan dan ritme bersangkutan, juga dibalik nama-nama tersebut terkandung pesan-pesan yang bersifat pendidikan, filosofi, dan etika. Berbicara tentang pesan, Roland Barthes (1984, 16-27, 33-46) sebagaimana dikutip oleh Budiman (2013: 2) bahwa ada dua tipe pesan yakni (1) pesan ikonik yaitu pesan yang dapat dilihat, dan (2) pesan simbolik atau pesan ikonik berkode.

Dengan demikian, pesan dari nama-nama dan atau istilah dari Ubit-bitan-ubitan di atas termasuk pesan tipe yang nomer 2 . Mengingat pesan yang ingin disampaikan terdapat di balik nama-nama dan atau istilah tersebut, sehingga tidak bisa dilihat secara langsung. Sebagai contoh (1) yang bersifat pendidikan. Ada Ubit-ubitan bernama Nyendok. Ubit-ubitan ini memiliki pengertian mnyentuh sebuah nada berturut-turut dua kali. Isyarat yang tersembunyi di balik pengertian ini adalah bahwa sering kali jika menyendok atau mengambil sesuatu dengan sendok tidak cukup dengan satu gerakan, perlu ada gerakan lanjutan. Hal ini mengandung maksud, bahwa di dalam usaha meraih sesuatu, jika tindakan pertama gagal, hendaknya diikuti dengan tindakan kedua niscaya akan berhasil. Jadi intinya nasehat yang terdapat di balik pemberian nama nyendok, dimaknai jangan cepat putus asa; (2) yang bersifat filosofi. Ada ritme bernama salah gatra. Pengertian ritme ditekankan pada kata "salah", karena seleh yang kuat terjadi pada gatra hitungan gajil. Lazimnya seleh yang kuat terjadi pada gatra hitungan genap. Kata salah di sini mengisyaratkan, bahwa manusia itu tidak ada yang sempurna, karenanya mereka tidak bisa luput dari kesalahan meskipun niat yang ada dalam benaknya adalah baik, ingin menghasilkan sesuatu yang sempurna; (3) yang bersifat etika. Ada Ubit-ubitan bernama Bolak-balik Nuduk dan Bolak-balik Ngutang. Kata nuduk yang mengikuti kata bolak-balik, diartikan dengan memunggut, bisa juga diartikan dengan mengambil atau menerima. Ngutang berarti membuang/meninggalkan, bisa juga bararti memberikan. Kedua pengertian, nuduk dan ngutang mengandung maksud bahwa di dalam hidup ber- 
masyarakat kita harus siap selain menerima sesatu, juga harus siap memberi sesuatu kepada orang lain.

\section{Penutup}

Gending-gending gêndér wayang memiliki berbagai jenis motif ubit-ubitan dan hiasan ritme. Realitas ini dapat diamati dari gending-gending untuk mengiringi pertunjukan wayang parwa. Dengan demikian penilaian berbagai kalangan, bahwa dalam gending-gending gêndér wayang terdapat berbagai jenis ubit-ubintan memang ada benarnya. Demikian pula dengan pernyataan I Made Bandem, bahwa dalam gending-gending gêndér wayang kaya dengan jenis ritme memang terbukti. Sayangnya, belum ada nara sumber yang bersedia untuk memberikan nama, sehingga penulis memberanikan diri untuk memberikan atau menawarkan beberapa nama dalam tulisan ini. Nama-nama yang ditawarkan tersebut, mengacu dari nama yang terdapat dalam perangkat gamelan Bali yang bukan gêndér wayang. Sebagai contoh nama teknik ngumad diadopsi dari nama teknik tabuhan instrumen trompong yang terdapat dalam perangkat Gong Gede, Gong Kebyar, dan Semar Pagulingan. Demikian pula nama teknik nuduk dan ngutang, diadopsi dari tenik tabuhan instrumen gêndér rambat yang terdapat dalam perangkat gamelan Semar Pagulingan Saih Lima. Adapun nama-nama lainnya seperti ubit-ubitan nyendok, oles-olesan, tulak wali, uber-uberan, dan nyalud, mengacu kepada nama yang diberikan oleh I Made Bandem. Sementara itu, nama-nama yang ditawarkan dalam ritme, seperti nguluin, ngumad, ngambang, ngantung, kesiab, imbuh nada, imbuh gatra, dan salah gatra, adalah hasil dari inpirasi yang diperoleh dari nama-nama yang diberikan oleh I Made Bandem.

Pemberian nama terhadap ubit-ubitan dan ritme di atas, selain mengacu dan atau mengadopsi dari gamelan Bali lainnya, juga didasarkan atas bentuk dan karakter dari permainan masing-masing ubit-ubitan dan ritme tersebut. Di balik nama-nama dan atau istilah tersebut ternyata mengandung pesan-pesan yang bersifat pendidikan, filosofi, dan etika. Begitu pula, nama-nama atau istilah tersebut sudah sangat akrab bagi masyarakat (seni) Bali.

\section{Kepustakaan}

Ardipal, A. (2016). Peran Partisipan sebagai Bagian Infrastruktur Seni di Sumatera Barat: Perkembangan Seni Musik Talempong Kreasi. RESITAL: JURNAL SENI PERTUNJUKAN, 16(1), 15-24. doi:http://dx.doi.org/10.24821/ resital.v16i1.1271

Bandem, I Made. (1983). Ensiklopedi Gamelan Bali. Proyek Penggalian, Pembinaan Pengembangan Seni Klasik/Tradisional dan Baru, Pemerintah Daerah Tingkat I Bali.

Bandem, I Made. (1986). Prakempa: Sebuah Lontar Gambelan Bali. Denpasar: Akademi Seni Tari Indonesia.

Bandem, I Made. (1993). Ubit-Ubitan; Sebuah Teknik Permainan Gamelan Bali. Mudra, Jurnal Seni Budaya Edesi Khusus Pebruari.

Budiman, C. (2013). Retorik dan Makna Ideologis Karya Instalasi dalam Film Opera Jawa Garin Nugroho. RESITAL : JURNAL SENI PERTUNJUKAN, 14(1). doi:http://dx.doi. org/10.24821/resital.v14i1.390

Dibia,I Wayan. (1997). Seni Pertunjukan Turistik dan Penggeseran Nilai-Nilai Budaya Bali. Mudra Jurnal Seni Budaya. 5 (5)

Hastuti, Bekti Budi. (2006). Gending Ki Nartosabdho Sebagai Inspirasi Penciptaan Tari Nini Thowok. RESITAL : JURNAL SENI PERTUNJUKAN. VII/O1.

Rembang, I Nyoman. (1977). Daftar Klasifikasi Gaemelan Bali. Kertas Serasehan Karawitan Bali. diselenggarakan oleh Pusat Pengembangan Kebudayaan Jawa Tengah, Agustus 1977.

Sukerna, I Nyoman. (1989). Gending-Gending Iringan Pakeliran Wayang Parwa Gaya I Wayan Konolan. [Laporan Penelitian]. Surakarta: Sekolah Tinggi Seni Indonesia.

\section{Audio}

Gamelan Gêndér Wayang Br. Babakan Desa Sukawati, Rick'S Record.

Gêndér Wayang Bajar Taman, Krobokan, Kuta, Badung (koleksi diskotik STSI Surakarta) I Wayan Sueca, 1985, "Gamelan GêndérKayumas 
Resital Vol.17 No. 1, April 2016

Kaja Badung" Bali Sterio music cassette Vol. Tabuh-Tabuh Gêndér Wayang, Desa Tunjuk $1, \mathrm{~B}-643$

Tabanan, Aneka Record 